\title{
What can agricultural land use planning contribute to food production and food policy?
}

\begin{abstract}
Food Security and Food Sovereignty are two of the most important issues facing Food Policy. Maintaining productive farmland and sustainable farms as well as providing adequate volumes of foodstuffs have led to measures to protect farmland and farm activities in many countries. These include land use planning with agricultural zones and in some jurisdictions legislation to 'protect' agriculture in agricultural reserves. Are these tools adequate to maintain sustainable agricultures particularly around major urban and metropolitan centers. Agricultural zones and agricultural reserves in many jurisdictions have continued to experience removal of farmland in order to permit different types of urban development (e.g. residential development and industrial parks). An emerging response to this has been the integration of strategic development planning for agriculture in certain jurisdictions (e.g. the province of Quebec (Canada)), because this approach can integrate the necessary parameters to enable the development of sustainable agricultures, including how to respond to opportunities as well as adapting to emerging stressors. This approach also ideally requires the integration of farmers and their families as actors and participants in the strategic development planning process.
\end{abstract}

Keywords: land use planning, agricultural development, strategic development planning, food security, food sovereignty, Canada, Belgium, France
Volume 2 Issue I - 2017

\author{
Antonia Bousbaine, ' Chérine Akkari, ${ }^{2}$ \\ Christopher Bryant ${ }^{3}$ \\ 'Department of Geography, University of Liege, Belgium \\ ${ }^{2}$ Department of Geography and Environmental Management, \\ University of Waterloo, Canada \\ ${ }^{3}$ Department of Geography, University of Montreal, Canada
}

Correspondence: Christopher Bryant, department of Geography, Canada and School of Environmental Design and University of Montreal, Ontario, Canada, Tel 519-846-1361, Email christopher.robin.bryant@gmail.com

Received: March 28, 2017 | Published: May 26, 2017

\section{Introduction}

Formal Food Policy refers to both food security and food sovereignty. It arises not just through formal government initiatives and intervention and it has often been connected to informal nongovernmental initiatives which have ended up being accepted by government ministries or agencies. In this article, the interest is on both formal and informal initiatives and in particular the role of different types of planning for agricultural development, how they have evolved recently in some jurisdictions and their contributions to food security and food sovereignty.

Both food security and food sovereignty have gained much attention in the last 20 years both in countries of the North and South, certainly with greater acuity in the South where food security is far from being achieved. It should be remembered that, after the First World War, this concept was widely disseminated among the European populations, who had access to cheap food, and farmers were reasonably remunerated. The notion of food security was also developed very early in the founding texts of the Common Agricultural Policy in the European Union.

This first use of the term "food security" was achieved through productivity agriculture, which was able to guarantee an abundant supply of food to food markets for European countries. However, food security also started to raise many questions from the 1940s onwards. At the World Food Summit in November 1996, it became clear that despite this so-called "productivist" agriculture, food insecurity is still widespread and encompasses much more than just the quantity of food made produced and includes issues relating to human health, environmental quality especially water resources and social issues relating to access to adequate and healthy food by certain populations. ${ }^{1}$ Some continents are more severely affected than others, e.g. Africa and Asia, ${ }^{2}$ and the situation has become more critical in some countries in these continents. ${ }^{3,4,5,6}$ The ultimate objective of the 1996 Summit was to eradicate hunger and half the number of people suffering from malnutrition by 2015 . Evidently by 2016 this figure had changed little and the populations suffering from food insecurity remain numerous, even in so-called "rich" countries. Alternatives must therefore be put in place by both governments and citizens.

Above all, the related notion of "food sovereignty" or "local" food production has been "challenged" by the organization Via Campesina, an international peasant movement, created in 1992, which points to the agricultural productivity systems which, despite their high yields, have not been able to eradicate hunger in the world. This organization refused to sign the Declaration of the World Food Summit in 1996, given the importance still given to so-called "productivity" agricultural systems. The modern movement for LFS (local food systems) as an alternative to the conventional agricultural system started in Japan in the 1970s with the teikei, which means "putting the producer's face on the product". The teikei were organized around consumer cooperatives, whose members would link up with producers and even contributed to the work on the farm. ${ }^{8}$ A similar model was also adopted in Québec by Équiterre in 1995 where consumers, organized into groups, pay up front at the beginning of the growing season and receive deliveries of food baskets each week, thereby sharing the risks inherent in agricultural production). ${ }^{9}$ Besides non-governmental organizations (NGOs), there is a growing interest by the public for local food, mainly linked to the idea of food sovereignty - a global movement that aims to transform food systems into engines of sustainable development and social justice. ${ }^{9}$ La via Campesina was the first organization to develop the concept of food sovereignty in 1993 in Belgium as a more radical alternative to the International Federation of Agricultural Producers. ${ }^{10}$ Thus, the pursuit of food 
sovereignty implies that work should be undertaken in international treaty negotiations and human rights conventions in order to allow state sovereignty over food policy - i.e. to prevent interference from foreign powers in the policy-making process, lift restrictions placed by international trade agreements, and eliminate dumping practices. ${ }^{9}$

\section{Further definition of food security and food sovereignty}

"Food security" is much more than simply the definition given by the FAO. It encompasses four dimensions: availability, accessibility, stability and quality. ${ }^{11}$ These dimensions are not always taken into account by governments in planning and land-use planning with regard to the protection of agricultural land. The notion of food sovereignty is often presented in different ways in different jurisdictions. In Montreal, for example, in 2007 a definition of food sovereignty was developed by a Québec-based coalition for food sovereignty that included producer organizations, civil society groups, food distributors, and development organizations. The definition states that "food sovereignty means the right of people to develop their own food and agricultural policy, to protect and regulate national food production and trade in order to attain sustainable development goals, to determine their degree of food autonomy, and to eliminate dumping on their markets. Food sovereignty does not contradict trade in the sense that it is subordinated to the right of people to local food production, healthy and ecological, realized in equitable conditions that respect the right of every partner to decent working conditions and incomes". ${ }^{9}$ Food sovereignty encompasses food security and food safety.

The FAO of the United Nations and its policies promote safe, healthy and ecologically sustainable food production that is culturally appropriate. In Canada, the growth of the local food movement, e.g. the increasing number of local farmers' markets and citizen-based initiatives such as community gardens and local food councils and food policies all reflect the growing concern about food security and food sovereignty. In addition, the National Farmers Union, the Canadian Federation of Agriculture and Food Secure Canada are some of the national actors calling for changes in relation to food security and food sovereignty.

For some time, many actors especially governments (e.g. several U.S. states, several Canadian provinces, the Netherlands, and several other European countries) have considered that agricultural land use planning has a major role to play in maintaining food production and providing some guarantee for improving food security and contributing to food sovereignty. We argue that the traditional forms of land use planning are not adequate to ensure the protection neither of farmland resources nor of farm activities. Globally, there are still 795 million people who suffer from hunger, and an important share of this enormous part of the global population is located in so-called "rich" countries while more than $75 \%$ of the peasants of the countries of the South are the first ones affected. ${ }^{12}$ This is paradoxical, since the primary function of a farmer is to contribute to feeding the planet's

Table I Pertinent research themes and research approaches and tools population. There is therefore still a problem in the management of agricultural land itself as well as in our dominant model of agricultural production.

\section{The approach}

The essence of our approach is based on a synthesis of the existing bibliography, as well as examples from North America (Canada) and Europe (France and Belgium) and our own research experience. In Table 1 the main research domains, and approaches the authors of this article have used are summarized. Agriculture and its transformations particularly in peril-urban territories and urban spheres of influence has been a major research domain carried out in a variety of countries. This has led inevitably to an understanding of land use planning and the planned development of agriculture and food production, particularly the strategic planning of agricultural development, including how adaptation to climate change and variability can be integrated in agricultural development planning.

\section{Objectives}

The principal objective of this article is to present our argument that land use planning alone cannot guarantee food security nor food sovereignty even if these policy orientations are considered to be very important in various jurisdictions. Some studies have also shown that conventional agriculture is far from being the one capable of feeding the 9 billion people on the planet by $2030 .{ }^{13}$

The second objective is to present the argument that to achieve the objectives of food security and food sovereignty, it is essential that agricultural land use planning be integrated with agricultural development planning (and action) through a more holistic form of planning which for agriculture means dealing with the sustainability of farm activities, the integration of farmland protection with the other values associated with farmland and farming activities (i.e. the multifunctionality of farmland and farming activities) and the capacity of farming (of farmers and other actors implicated in or concerned with agricultural development) to cope with major stressors other than urban development and ex-urbanization such as climate change and variability. It will also be argued that the co-construction of viable projects that emphasize the nutritive function of agriculture for all populations is an essential component of such agricultural development planning and action.

This leads us to consider new forms of agriculture that are being established around the world, through "Urban" agriculture, which occupies the smallest spaces of the cities but which allows the most deprived populations access to a healthy, daily diet. ${ }^{14}$ In section 3 , we discuss the necessity to integrate agricultural development planning with land use planning, followed by the critical aspects needed in agricultural development planning in section 4 . In section 5 strategic development planning is discussed in greater depth. Conclusions are presented in section 6 .

\begin{tabular}{|c|c|c|}
\hline Authors & $\begin{array}{l}\text { Research themes and number of years of } \\
\text { research by each author in each research theme }\end{array}$ & Research approaches and methodological tools \\
\hline & $\begin{array}{l}\text { Agriculture - links between agriculture in peri-urban } \\
\text { areas and the city (in Wallonia) ( } 3 \text { years) }\end{array}$ & $\begin{array}{l}\text { Targeted interviews: online questionnaires - with farmers, neo-rural citizens, } \\
\text { key actors }\end{array}$ \\
\hline Bousbaine, $A$ & Governance processes in peri-urban areas (2 years) & $\begin{array}{l}\text { Interviews; upper level civil servants, politicians, elected officials, local } \\
\text { development officers, the designers of the Food Belt around Liège, action } \\
\text { research }\end{array}$ \\
\hline
\end{tabular}


Table Continued....

\begin{tabular}{ll}
\hline Authors & $\begin{array}{l}\text { Research themes and number of years of } \\
\text { research by each author in each research theme }\end{array}$ \\
\hline Understanding the adaptation process to climate \\
change and variability (CCV) at the farm level (3 years) \\
Agricultural land use planning (3 years) \\
Peri-urban agriculture (50 years) \\
Food security and food sovereignty (35 years) \\
Adaptation of human activities to CCV (30 years) \\
Community development, local economic development, \\
strategic development planning by and for the \\
community (citizens, collective actors) (30 years) \\
Environmental assessment as a tool for decision-making \\
in the context of sustainable development (I5 years) \\
Agro-environmental policies assessment (I0 years) \\
the dynamics of farmers and social systems to enhance \\
their CCV resilience and adaptability (8 years) \\
development of management plans for pastoral units \\
(5 years) \\
Agricultural vulnerability and capacity assessment, and
\end{tabular}

Why it appears necessary to consider agricultural development planning and not just land use planning

Concerns over food security and food sovereignty have given rise to various initiatives in which land use planning was used to protect farmland, especially the best quality farmland, from urban development and particularly from ex-urbanization processes. Certainly, land use planning has been considered as a major tool, for instance through legislation to protect farmland (notably in different parts of North America) as well as through strong governmental efforts to ensure effective land use planning in agricultural zones even if there was not specific farmland protection legislation in place. ${ }^{15} \mathrm{In}$ France as early as the 1990s, the agricultural development issue began to be integrated into Land Use Plans, and agri-urban programs began to be put in place to limit urban sprawl and support the protection of good farmland and healthy agricultural products. ${ }^{16}$ Nonetheless, it is still evident that the food security of a country like France is not fully achieved - between 2005 and 2012, the number of meals distributed by Restos du Coeur increased from 67 million in 2005 to 115 million in $2012 .{ }^{17}$

Thus, even where there is legislation in place to protect farmland (e.g. the provinces of British Columbia and Québec in Canada), it has clearly not been adequate when we observe the number of withdrawals of good quality farmland by government (e.g. provincial and local/regional governments). In addition to that, in Québec, only the food sovereignty policy ${ }^{18}$ explicitly addresses the inclusion of food sovereignty in land use planning policies; for instance, this has still not been integrated into the land use and development plan of the RCM of Haut-Richelieu, neither into its supplementary document, and into the urban plans. ${ }^{19}$

\section{Research approaches and methodological tools}

Public survey, interviews with farmers and government representatives, focus groups, key informant interviews, grounded-theory, statistical analyses

Interviews with citizens, elected officials and government representatives at different levels, key informant interviews, statistical analyses

Interviews with farmers, business owners, local elected officials, members of parliament, focus groups, forums involving a wide range of actors

Climate change modelling, modelling economic impacts on farm businesses, interviews with farmers, other local and regional officials, representatives of pertinent ministries; focus groups, forums, action research ...

Interviews with local elected officials, planners ... focus groups and forums involving citizens, following progress of strategic development plans over several years, action research ...

Public survey, focus group discussions, key informant interviews. statistical analysis

Ethnographic techniques, impacts assessment

Collection of field data, focus groups, informant interviews, multi-criteria and statistical analyses

Public surveys, focus group discussions, informant interviews, multicriteria and statistical analysis

Since 2013, food sovereignty policy has been used to integrate the concept of food sovereignty in the planning of Quebec's farmland. Indeed, this policy states that food sovereignty can hardly exist without the preservation of agricultural land for future generations. However, the application of this policy is still vague and it will take several years to assess its real impact on the development of agricultural land. Of course, there are many countries or major regional territories where effective farmland protection and management has not been a significant priority (e.g. Belgium).

When we investigate obstacles, policies and existing initiatives related to the nodes in the value chain in the literature, we notice there is a dilemma between land protection and land access. ${ }^{9}$ This can be mostly attributed to the case of land use zoning policy. In 1978, in the context of rapid economic development, speculation on land, land fragmentation and non-agricultural use, the government of Quebec passed its farmland protection legislation (Loi sur la protection des terres agricoles (LPTAA). This legislation also reflected a desire to plan and regulate in the farmland areas to be protected and thus a specific agency was created (the Commission de protection $d u$ territiore agricole $d u$ Quebec (CPTAQ)). This law is the only one of two in Canada (the other being British Columbia), and it has effectively contributed substantially to the protection and continued use of agricultural land over the years. However, today with greater concentration of land ownership and fewer people in the business of food production, this legislation has been seen by some observers as causing problems since it acts as a barrier to entry for smaller and more value-added producers who need smaller plots of land ${ }^{20}$ (Lemay, 2009). In fact, the farmland protection legislation is one of the laws that facilitates industrial or productivist agriculture at the expense of small-scale sustainable agriculture and short supply chains (e.g. zoning laws that favor big farms, subsidy systems that favor large- 
scale retailers and funding schemes targeted at large producers). At the same time, we can see this on an international level - the pressure for city expansion, land speculation and non-agricultural land use is still strong. Moreover, beyond the provincial level, municipalities have authority over certain zoning by-laws that can facilitate or inhibit the development of local farming systems (LFS), particularly regulations concerning the use of agricultural zones for commercial purposes. ${ }^{9}$ Though aimed at protecting agricultural zones from industrial development and other forms of encroachment, such by-laws effectively prevent on-farm direct sales or the use of farmland for farmers' markets or farm shops ${ }^{21}$ and organizers of such initiatives typically have to negotiate with municipal authorities for special permits or designated spaces. ${ }^{22}$ However, agricultural zoning designations for tax purposes falls within the provincial government jurisdiction or a land management agency, such as the Agricultural Land Reserve agency in British Columbia or the Commission pour la protection des terres Agricola du Québec. ${ }^{9}$

We can also investigate Belgium where for long little attention had been focused on protecting farmland to ensure food production. Today, the central state and provincial authorities have finally begun to realize the importance of putting in place a more appropriate territorial management in line with the population's food needs. ${ }^{23}$ This new Regional Territorial Development Scheme (SDER) for the moment concerns only Wallonia, where there are more and more advocates for using agricultural land with "parsimony". Nevertheless, in parallel, we note that this SDER recommends that every year an area of this territorial space be identified and removed from its agricultural function in order to install "Zoning" (Industrial or Economic Activity Parks). Evidently, once more agricultural land use planning alone is not sufficient in itself to guarantee future food production to contribute to either food security or food sovereignty.

\section{What does agricultural development planning need to consider?}

The discussion in this section is organized into four sub-sections: sustainable agriculture, the multi-functionality of farmland and farming activities, recognizing the need to take into account other stressors affecting farmland and farm activities, and also recognizing that government intervention can restrict the development of certain types of sustainable agricultural systems. A number of important issues if effectively dealt with can reinforce the protection of farmland and farm activities and provide a better guarantee of improving food security and contributing to food sovereignty. This will be argued both at the national and regional scale, as well as at the global scale where certain stressors such as climate change have already reduced the capability of some countries to satisfy their own food needs (e.g. some African countries such as Ethiopia). Food security in some subSaharan African countries is becoming increasingly critical, given the agricultural policies developed in these countries, where export crops have largely overtaken local food crops, and where climatic conditions, with increasingly severe droughts, have been affecting more and more farm families. As the FAO's report referred to earlier points out, the problem of soil fertility is becoming a recurring and worrying issue. Real soil management policies need to be put in place in these countries to ensure food security for these populations. The dominant agricultural models, especially productivity agriculture, in the Western world does not contribute much to helping these countries achieve self-sustainability, which not only affects access to local food but also contributes to reducing the number of small-scale local producers; furthermore, engaging in the production of crops in line with productivity agriculture also contributes to encouraging many rural laborers and peasant farmers to move to slums in cities as they no longer have access to their critical work tool: land.

\section{Sustainable agricultures}

First, Local food systems have been proliferating in Quebec. ${ }^{20}$ There is a growing interest in the production, processing, and purchase of local food. New "local food systems" are being set up to organize the various components to meet the food needs of all stakeholders in the community or region. ${ }^{24}$ The initiatives that are part of this process in Quebec are: organic and other specialized agricultures (there were 316 certified organic livestock production units, 341 organic maple syrup producers, and 585 certified farms in 2009 in Québec), ${ }^{25}$ farmer's markets (with a network of 82 open markets, that are seasonal or permanent, daily or occasional), Community Supported Agriculture (CSA) (Équiterre runs one with over 100 participating farms. Others include: the Union paysanne, La Mauve (Coop CSA)), and solidarity markets. ${ }^{20}$ Despite the increase in these initiatives, there are three main obstacles that slow their expansion: lack of financing (e.g., banks are not willing to issue micro-loans at competitive rates), economic power (e.g. the food retail sector is marked by high rates of market concentration; supermarkets have been able to achieve economies of scale because they do not have to pay for the social and environmental costs of their business practices), and knowledge (the lack of demand for local food attributed to a lack of information about where to procure it and about prices).

Protecting agricultural land depends also upon supporting agricultures (i.e. different systems of agricultural production) that are sustainable in relation to the income generated for the farmers and their families; farms that are not capable of generating adequate income for farmers and their families (or the corporations involved in the case of very large farms) present one of the first signals of weakness and unfortunately facilitates the removal of farmland from an agricultural reserve or an agricultural zone. This is the major reason why it is important to engage in the construction of a development plan for agriculture and not just rely on the "protection" of farmland.

In a country such as Belgium, for some years the Walloon Region has supported a more sustainable agriculture through aid granted to organic farming. This involved 37 farms in 1987 increasing to 1347 in 2015, covering an area of approximately 63,437 hectares in 2005 and increasing to 21,225 hectares in $2015 .{ }^{26}$ But it is above all the initiatives emanating from citizens that are beginning to emerge, which give a real impetus to the sustainability of agricultural systems and their durability over time. In Belgium, in the Province of Liège, a coalition of citizens has created a Food Belt (Ceinture Alimenterre), ${ }^{27}$ with production systems based on small farms, based on agro ecology. This Belt aims to facilitate access for all to food produced under ecologically and socially decent conditions that strengthen the populations' food sovereignty and support and develop models of agriculture that are less dependent on non-renewable energies. This initiative has begun to take root in the Province of Liège and efforts are being made to promote the same approach throughout the Walloon region. Two of their projects ("Agricultural Relay Hall Mortier" and "Shared Workshop of Organic Fruit and Vegetable Processing in Liège") were selected by the Walloon Minister for Agriculture on $21^{\text {st }}$ July 2016 as key projects to improve the value of Walloon agricultural production and provide local populations with a healthy and sustainable diet. ${ }^{28}$ 
In France, many initiatives also already exist, in a sense supported by metropolitan areas, such as Nantes Métropôle Agricole and Rennes, a Food City. All these initiatives aim to ensure the food sovereignty of the cities by ensuring the sustainability of agricultural territories. De facto this implies a form of territorial planning where all the actors become involved, including the farmers, but also the citizens and the political authorities. The aim is to ensure access for all to Healthy eating while preserving the environment.

To respond to this issue requires that agricultural land use planning be combined with agricultural development planning in which farmers, their families and other actors are involved. This has been happening in Quebec since 2008 when the province launched a pilot project (involving 8 Regional County Municipalities (RCM) ${ }^{29}$ to construct PDZAs (Plans pour le Développement des Zones Agricoles, or Development Plans for the Agricultural Zones)) which was subsequently extended to other RCMs with agricultural zones. This type of development planning fits into the broader context of strategic development planning by and for the communities involved, with agricultural development representing one of the key strategic orientations in the communities/regional municipalities/counties in which agriculture occupies an important area of land.

Moreover, in some European countries (notably France and Belgium), citizens have themselves seized upon this food issue, by developing sustainable agricultural models such as "Companions of the Earth" ${ }^{30}$ (2017), by developing Cooperatives of agricultural production, through the Local Development Agency present in the commune. Thus, a certain form of "food governance" takes shape, involving all the actors. In addition, awareness of the means of supplying cities has been the subject of much research in the last ten years. Many researchers have been studying food sovereignty, which directly calls into question the productivity agricultural system. Some authors refer to "food justice", ${ }^{31}$ through urban agriculture, which provides access to food sovereignty in certain neighborhoods of wealthy countries such as the United States. This phenomenon of alternative systems taking shape in many countries is further developed below.

\section{The multi-functionality of farmland and farming} activities

Second, we note that the concept of multi-functionality of agriculture came into being at the Rio Summit in 1992, alongside Sustainable Development, and the goal was to achieve agricultural production that respects the environment. In reality, this concept had already been evoked in Anglo-Saxon countries much earlier, ${ }^{32}$ but under a different name, that of multi-purpose use. Although this concept has been partially taken into account by all actors, for farmers it remains "blurred". Indeed, in Wallonia, the many farmers surveyed in the framework of a Master's research project, ${ }^{33}$ the lack of appropriation of this concept by the agricultural population was noted. To make more effective use of this concept (also a tool), a greater involvement has to be made by local authorities, such as through their Local Development Officers. This involvement makes it possible, as we have seen in certain projects that are set up to ensure better land use in Wallonia, where agricultural land can reach exorbitant prices of up to 40,000 euros per hectare (in France, the average is about 6,500 euros / ha. ${ }^{34}$ which makes access to land and therefore food sovereignty much more difficult.

In some parts of Canada and other countries there is increasing emphasis placed on the multi-functionality of farmland and farm activities (such as ecological services, tourism value of landscapes, landscape conservation (e.g. the legislation for protecting humanized landscapes in Quebec), and several other functions (Table 2). Some functions are market functions in the sense that they generate income for farmers and others are non-market functions. ${ }^{35}$ One of the keys for the protection of farmland and farming activities is that these functions can be appropriated by non-farm populations (and governments as well) and this increases the weight of (political) support given to farmland protection. There are some countries where this type of support is very limited (e.g. Belgium) and where the most powerful actors (governments, developers) only seem to have one perspective, and that is withdrawing farmland from agricultural zones for industrial park development! Or to accommodate upmarket residential development. Multi-functionality was strongly recommended by the Quebec government to the RMCs in relation to involving non-farm actors in developing agricultural development plans in agricultural reserves from 2008 onwards. The issue of multifunctionality has also been given a very high profile in many West European countries since the mid-1980s.

\section{Recognizing and dealing with other stressors, such as climate change and variability}

Third, there is a need in constructing development plans for agriculture to consider other stressors affecting agriculture (other than just urban development and ex-urbanization). Of major importance are the effects of climate change and variability which is now being recognized in more and more countries as significant for agriculture. Dealing with this stressor can make a major contribution to dealing with the challenges of food security both for our own populations and for the populations of many developing countries where their own agriculture is no longer capable of fulfilling their own food needs (e.g. Ethiopia).

Table 2 Principal functions of farmland and farm activities near cities

\begin{tabular}{ll}
\hline Four broad categories of collective functions & Specific collective functions \\
\hline $\begin{array}{ll}\text { Functions depending more on the location of peri- } \\
\text { urban spaces (place functions) }\end{array}$ & $\begin{array}{l}\text { A place of residence and work (industrial and commercial development) } \\
\text { A place for the development of certain tourist and recreational activities }\end{array}$ \\
$\begin{array}{l}\text { A place where projects can be developed for the integration of marginalized urban } \\
\text { (and other) populations (e.g. on "community" farms). }\end{array}$ \\
$\begin{array}{l}\text { Leisure and touristic functions (play functions) } \\
\text { A place for the development of touristic activities }\end{array}$
\end{tabular}


It is true that in some countries such as Canada, the phenomenon of climate change is making headway, but within the European Union, little has been done at the level of the "advice" or information provided to farmers. However, some ASBL (Associations sans but lucrative or Non-Profit Associations) such as Terre en vue recently sent an announcement to encourage support to farmers whose productions are destined to feed the population. Indeed, the bad weather in June and July of 2016 strongly affected the production of certain market gardeners in the Walloon Region, causing a loss of profit and a loss of autonomy for consumers asking for local products. In this sort of context, it becomes important to take planning measures by integrating climate change and variability into agricultural development plans and to actually support those farmers who are trying to provide healthy and sustainable food to local consumers. One of the first jurisdictions to do this is the province of Québec in Canada, which launched a pilot project in September 2016 for an RCM to integrate this phenomenon and the adaptation of agriculture to climate change and variability into the PDZA (Bryant has been appointed as one of the members of the steering committee for this pilot project). It is expected that by the end of the summer 2017 this process of integrating climate change and variability and farm adaptation to it will be extended to the other RCMs in the province. This will undoubtedly have a positive effect upon food security and food sovereignty in Québec Source: Developed from. . $^{32,35}$

\section{Recognizing that many government policies can actually restrict the development of new forms of sustainable agricultures}

Agriculture is a major driver of human-caused climate change, contributing an estimated 25 to $30 \%$ of global greenhouse gas emissions. However, with sustainable agricultures, agriculture can become an important key to mitigating climate change. ${ }^{36}$ The sustainable use of agricultural biodiversity is likely to be particularly beneficial for small-scale farmers, who need to optimize the limited resources that are available to them and for whom the access to external inputs is lacking due to financial or infrastructural constraints. ${ }^{37}$ Benefits on a large-scale can also be achieved by focusing on improvements relevant to large commercial farms and conservation agriculture has already been effective in this respect. Inevitably, there is considerable skepticism over the practicality of the widespread adoption of agricultural production practices that embody a greater use of biodiversity for food and agriculture and a greater emphasis on ecosystem functions. ${ }^{38}$ Two major geopolitical realities have a constraining effect on peoples' thinking. First, modern, intensive farming in developed countries receives very large levels of financial support and all sectors of the agricultural and food industries are linked in to this highly subsidized system to a greater or lesser extent. Second, there is a continuing commitment to ensuring that food prices remain low and that basic foodstuffs are affordable by all segments of society including the poorest. These both tend to lead to a disinterest in the nature of agricultural production systems and present a very real barrier to the development of new approaches to production. ${ }^{38}$ However, it is increasingly recognized that an appropriate policy framework can largely overcome these constraints and, indeed, must be developed. ${ }^{37}$

Finally, another major problem concerns the approaches that many governments (several provinces in Canada, and several other countries as well) have used to regulate farmland in agricultural zones and reserves to support capitalistic/productivity agriculture; for instance, in regions where the property structure is dominated by large scale property parcels, several governments are still effectively preventing the development of the small (in a real size) farms capable of yielding high yields in an environmentally sustainable manner because their way of thinking is still being influenced by what was happening to farmland by ex-urbanization processes in the 1950s and 1960s. Again, this type of thinking does not fit very well with the thinking of an increasingly large segment of the consumer market or with preoccupations about food security. Today we can only note the fact that we must literally change our models of agricultural production, and seriously consider new forms of agricultural production, really designed to ensure the food security of local consumers and consequently their sovereignty.

\section{Strategic planning for agricultural development}

The fundamental question that has arisen concerning land use planning for agriculture is how to construct a strategic development plan for agriculture in agricultural zones or reserves and who should be involved in constructing these plans. Clearly there are differences between countries and even territories in the same country. However, because of the significance of having people on the ground involved, it is inevitable that farmers and their families, farm organizations with local representation as well as the appropriate local and regional municipalities must be involved. In terms of the specificities of different territories, it may be important to have people from the tourist industry involved as well as environmentalists. The fundamental characteristics of strategic planning for development are presented and discussed, drawing upon the extensive practical and professional work in this domain by Bryant. ${ }^{39,40}$

This includes the basic steps in such strategic development planning, as well as the possibility of identifying three types of Strategic Orientations:

I. Geographic Orientations (e.g. downtown areas, flood plain zones, and ... agricultural reserves and zones;

II. Sectoral Orientations (e.g. agriculture, tourism, industry ...);

III. Transversal Orientations which cut across many if not all of the other Strategic Orientations (e.g. climate change and variability, effective mobilization and communication with the population and various collective actors, education).

A basic strategic development plan for agriculture (a sectoral orientation) in an agricultural zone (a geographical orientation) is a combined sectoral-geographic strategic orientation, i.e. a Strategic Orientation that has a Geographic component (i.e. the agricultural reserve or zone) and a Sectoral component (i.e. agriculture) but which also will likely contain various Transversal components that can be integrated into the development plan for agriculture (e.g. climate change and variability, food market evolution, effective communication with the different actors including citizens...). The overall strategic development plan for the whole territory under consideration (e.g. a region, a RCM ...) also integrates in our case an agricultural development plan for an agricultural reserve of zone(s)). Generally, a Working Group (or a Steering Committee) for such a strategic orientation can include representation of the different segments of legitimate interest in terms of what happens to agriculture and how it develops, and for agricultural development this can include non-farmers who live in the same agricultural reserves and zones, organizations involved in rural tourism development in agricultural 
areas and environmental associations. The involvement of non-farm interests (because of their preoccupations and values associated with the different functions of farmland and farming activities) can easily provide the basis for a governance process for these agricultural reserves and zones. This can also be found in development plans put together by farmers and other actors, together with the support of researchers undertaking the roles of action research. ${ }^{41,42}$

\section{Discussion}

Today, more than ever, all countries are fully aware of the issue of food security and food sovereignty. The food crises that have affected much of Africa, Asia and South America in 2008 and 2009 emphasized the urgency of tackling this problem, and of undertaking a fundamental review of our agricultural productivity system, which, while it is performing well and provides ample food overall for the 7 billion people on the planet, fails to ensure food security. There are still too many people affected by food insecurity. Although territorial development planning programs have been set up to preserve and protect agricultural land, the results remain mixed. Many authors ${ }^{1,6,743-45}$ have tried to demonstrate the limits of the productivity system and have thus put forward alternative systems, e.g. Organic farming, short circuits, AMAP (Association for the Maintenance of Peasant Agriculture), GASAP (Solidarity Buying Group for Peasant Agriculture, Terre en vue, Terre de Lien). But we have argued that land use planning of the territories does not in itself ensure the food security of its territories nor reinforce food sovereignty.

In addition to land use planning, the local authorities must encourage other forms of agriculture which take into account the sustainability of the territories and give a role to these agricultures, especially to help the farmers and their families. Besides the farmers, who have become minorities, citizens have a crucial role to play. It should be noted that the initiatives taken to attain sovereignty emanate in many cases from private actors outside the agricultural world..$^{27,46}$

Just as in recent years, special attention has been paid to this so-called "Urban" Agriculture (more than 800 million people practiced this around the world. ${ }^{33}$ For some, it is almost a fashionable phenomenon that has been appropriated by segments of the well-todo populations ${ }^{31}$ others have demonstrated its role in securing food for the most deprived social classes. ${ }^{45}$ There are so many examples, even in a region like Brussels-Capital where the First School of Urban Agriculture in Belgium took place in July 2016. The role of this agriculture in the most impoverished districts is to be noted. The multiplication of collective or shared gardens becomes essential for certain segments of the Brussels population, who struggle to have a healthy diet on a daily basis.

\section{Conclusion}

The principal conclusions from the examples presented demonstrate that it is in fact quite possible to construct (in effect, co-construct) agricultural development plans by using the principles of strategic development planning by and for the community (citizens and the various collective actors). To achieve the vision of food sovereignty presented earlier, LFS have to go beyond the issue of the distance travelled by food products before they reach the final consumers (food miles) and integrate social, economic and environmental benefits. Also, farmers' markets, CSA and other initiatives are becoming increasingly present in industrial countries in recent years, but they still only represent a very small part of the food market. ${ }^{9}$ For example, in Quebec, Équiterre's CSA went from one to 102 farms between 1995 and 2006 . It contributes to $73 \%$ of the average turnover of the farms involved, and yields an average annual profit of $\$ 3,582$ annually when conventional agriculture produces an average annual loss of $\$ 6,255 .{ }^{47}$ In addition, there are interesting possibilities in relation to zoning laws and farmland protection legislation. In fact, even within existing legislation, new initiatives are emerging and new possibilities can be developed in other provinces and countries. These include cooperative land trusts and the collective buying of land and green belts). ${ }^{20}$

However, other aspects require reform. Québec, the CPTAQ should be more flexible to LFS needs. For example, in one case, the CPTAQ has agreed to allow the municipal authorities of Ste-Camille to take on the management of a large farm that was for sale in order to help new young families establish small farms. In order to do this, the CPTAQ de-zoned the land, thus technically empowering the municipal authorities to develop it however they chose, though there was an understanding that the municipality would keep the land for agricultural use. If this case is inspiring, there should be a formal way to make such arrangements without necessarily de-zoning the land and placing it at risk. Even though there may be no national policy to promote LFS in numerous countries, some governments have been active with various pertinent programs, e.g. for the support of organic farming.

Other elements remain crucial to ensure a healthy daily diet for the population, who are more and more inclined to know the origin of the products consumed and put a "face" on the producer. The political authorities are beginning to identify certain key elements, such as the sustainability of agricultural systems, the importance of taking account of consumer choices, adaptation to climate change, ${ }^{48}$ which will only enhance the food security of their territory and allow certain food self-sufficiency in their country. Especially over the last ten years, alternative models of agricultural production have been set up, so that the productivity system can be replaced ${ }^{44}$ particularly because of its negative externalities. Thus, genuine consultation and taking into account the demands of the different actors can lead countries to halt the problem of hunger in the world by co-constructing sustainable alternative systems that are more respectful of the environment and public health, and ultimately put into practice a food governance system that draws together the legitimate interests of the different segments of the population. ${ }^{49,50}$

\section{Acknowledgements}

None.

\section{Conflict of interest}

The author declares no conflict of interest.

\section{References}

1. Touzard JM, Temple L. Sécurisation alimentaire et innovations dans l'agriculture et l'agroalimentaire: vers un nouvel agenda de recherche? Une revue de la littérature Cahiers Agricultures Volume. 2012;21(5):293301.

2. FAO. The state of food insecurity in the world. 1999.

3. Azoulay G. Globalisation des échanges et sécurité alimentaire mondiale à l'horizon 2010 Revue. Tiers Monde. 1998;39(153):25-43.

4. Maxwell S, Slater R. Food Policy Old and New. Development Policy Review. 2003;21(5-6):531-553.

5. Janin P, Dury S. Les nouvelles frontières de la sécurité alimentaire. Cahiers Agricultures. 2012;21(5):285-292. 
6. Brondeau F. Comment sécuriser l'accès au foncier pour assurer la sécurité alimentaire des populations africaines: éléments de réflexion. Revue électronique Vertigo. 2014:14(1).

7. Mundler P. Les Associations pour le maintien de l'agriculture paysanne (AMAP) en Rhône-Alpes entre marché et solidarité. Ruralia. 2007 :20.

8. Pretty J. The Living Land: Agriculture Food and Community Regeneration in Rural Europe. London: Earthscan; 1998.

9. Blouin C, Lemay JF, Ashraf K, et al. Local food systems and public policy: a review of the literature. Équiterre \& The Centre for Trade Policy and Law Carleton University; 2009.

10. Pimbert M. Towards Food Sovereignty: Reclaiming Autonomous Food Systems. London: International Institute for Environment and Development; 2008.

11. Caplat J. Changeons d'agriculture: Domaine du possible. Actes Sud. 2014:152.

12. IFAD. Report Rapport sur la pauvreté rurale Synthèse. 2011:15.

13. Rennes citroën Agrocampus Ouest. 2017.

14. Aubry C, Pourrias J. L'agriculture fait déjà partie du métabolisme urbain Démeter 2013 Paris. 2013:135-155.

15. Bryant CR. Russwurm LH North American farmland protection strategies in retrospect. Geo Journal. 1982;6(6):501-511.

16. Bonnefoy S. Ville et agriculture périurbaine:la trajectoire française. Scienze Del Territorio. 2013;1:185-194.

17. Europe 1. 2012.

18. MAPAQ Politique de souveraineté alimentaire du Québec. 2013.

19. Akkari C, Bryant CR. Connell DJ Agricultural Land Use Planning in Canada: Case Study of RCM of Haut-Richelieu Final Report -CaseStudy-Final-Report-Haut-Richelieu-104pdf. 2015.

20. Lemay JF. Local Food Systems and Public Policy: The Case of Zoning Laws in Quebec. 2009

21. Wormsbecker CL. Moving Towards the Local: The Barriers and Opportunities for Localizing Food Systems in Canada Master of Environmental Studies in Environment and Resource Studies University of Waterloo. 2007.

22. Connell DJ. R Borsato; Gareau L Farmers Farmers Markets and Land Use Planning: Case Studies in Prince George and Quesnel University of Northern British Columbia. 2007:2(46).

23. SDER Nouveau Schéma de Développement de 1'Espace Régional. 2013.

24. Irshard H. Local Food-A Rural Opportunity Government of Alberta Agriculture and Rural Development. The Argument for Local Food. 2009;16(3):21-30.

25. CARTV Conseil des appellations réservées et des termes valorisants. Statistiques pour l'appellation biologique. 2009.

26. Spw. 2015.

27. La Ceinture aliment-terre liégeoise émane d'une coalition d'acteurs citoyens, économiques et culturels de la région liégeoise engagés dans le projet de transformation en profondeur du système alimentaire regional. 2012 .

28. Walloon Government. 2016.

29. Bryant CR, Marois C, Granjon D, et al. Agricultural land protection in Quebec: from provincial framework to local initiatives. In: Caldwell W, Hilts S, Wilton B, editors. Farmland Preservation-Land for Future Generations. 2nd ed. Guelph: Centre for Land and Water Stewardship University of Guelph; 2017.

30. Companions of the Earth. 2012.
31. Paddeu F. De la crise urbaine à la réappropriation du territoire Mobilisations civiques pour la justice environnementale et alimentaire dans les quartiers défavorisés de Détroit et du Bronx à New York PhD thesis École doctorale de Géographie de Paris Espace sociétés aménagement (Paris). 2015. 585 p.

32. Bryant CR, Johnston TRR. Agriculture in the City's Countryside. London: Pinter Press and Toronto: University of Toronto Press; 1992. $226 \mathrm{p}$.

33. Bousbaine A. Facteurs d'évolution et de transformation de l'agriculture dans les communes périurbaines de Charleroi de 1990 à 2010 Master 2 thesis ULB. 2014. 140 p.

34. SAFER La Safer Réunion participe au développement durable de l'île. 2015.

35. Bryant CR. La place des espaces ruraux périurbains et de l'environnement dans le développement régional. In: Mollard A, Sauboua E, M Hirzak, editors. Territoires et enjeux du développement régional Versailles: Éditions Quæ. 2007. p.159-171.

36. Nierenberg D, Reynolds L. Supporting Climate-Friendly Food Production. WorldWatch Institute; 2012.

37. FAO Situation mondiale de l'alimentation et de l'agriculture en 2010 2011 Le rôle des femmes dans l'agriculture Combler le fossé entre les hommes et les femmes pour soutenir le développement. 2011.

38. Naman K. FAO Biodiversity for Food and Agriculture: Contributing to food security and sustainability in a changing world Platform for Agro biodiversity Research. 2011.

39. Bryant CR. Strategic Management and Planning for Local and Community Economic Development: I The Community Sustainable Community Analysis Workbook 3. St Eugène Ontario: Econotrends Ltd; 1995. 56 p.

40. Bousbaine A, Bryant CR. Les défis des communautés côtières pour rehausser la résilience et leur capacité à faire face aux intempéries climatiques. 2015.

41. Bousbaine $\mathrm{AD}$, Bryant $\mathrm{CR}$. The integration of action research and traditional field research to provide sustainable solutions to maintaining periurban agriculture. Geographical Research. 2015;54(2):1-11.

42. Bryant CR, Chahine G. Action research and reducing the vulnerability of peri-urban agriculture: a case study from the Montreal Region. Geographical Research. 2015;54(2):165-175.

43. Lamine C, Chiffoleau Y. Reconnecter agriculture et alimentation dans les territoires: dynamiques et défis. Pour. 2012:n215-216.

44. Fournier S, Touzard JM. La complexité des systèmes alimentaires: un atout pour la sécurité alimentaire. Revue Vertigo. 2014:14(1).

45. Duchemin E. Armer les villes contre a faim: systèmes alimentaires urbains durables. 2010.

46. Santropol Roulant. 2017.

47. Chinnakonda D, Telford L. Les économies alimentaires locales et régionales au Canada: rapport sur la situation Ottawa: Agriculture et Agroalimentaire Canada. 2007.

48. Bryant CR, Sarr MA, Délusca K. Agricultural Adaptation to Climate Change. Netherlands: Springer; 2016.

49. Akkari C. Adaptation of agriculture to climate change in Québec: the co-construction of agricultural policies in the RCM of Haut-Richelieu Montreal: University of Montreal Master's thesis in Geography. 2015.

50. Akkari C, Bryant CR. The co-construction approach as approach to developing adaptation strategies in the face of climate change and variability: a conceptual framework. Agricultural Research. 2016;5(2):162-173. 